УДК 377.111 .3

DOI:

Ірина Гириловська, кандидат педагогічних наук, докторант Інституту професійно-технічної освіти НАПН України, м. Київ

\title{
ОРГАНІЗАЦЙНО-ПЕДАГОГІЧНІ УМОВИ ПРОВЕДЕННЯ МОНІТОРИНГУ ЯКОСТІ ПРОФЕСІЙНОЇ ПІДГОТОВКИ МАЙБУТНІХ КВАЛІФІКОВАНИХ РОБІТНИКІВ
}

У статті подано теоретичний аналіз поняття “організаційно-педагогічні умови” в контексті моніторингу якості професійної підготовки майбутніх кваліфікованих робітників; представлено авторське бачення даного виду моніторингу, його особливостей, етапів проведення; зазначено перелік моніторингових заходів, призначених для його реалізації; виокремлено та охарактеризовано організачійно-педагогічні умови успішного здійснення моніторингу якості професійної підготовки випускників у професійно-технічних навчальних закладах.

Ключові слова: моніторинг; моніторингові заходи; умова; організачійно-педагогічні умови; професійна підготовка; майбутній кваліфікований робітник; професійно-технічний навчальний заклад.

Jim. 5.

Iryna Hyrylovska, Ph. D.(Pedagogy), Doctoral Student of the Institute of Vocational Education National Academy of Educational Science of Ukraine, Kyiv

\section{THE ORGANIZATIONAL AND PEDAGOGICAL CONDITIONS OF CONDUCTING THE MONITORING OF QUALITY OF PROFESSIONAL PREPARATION OF FUTURE QUALIFIED EMPLOYEES}

The reformation of national vocational education causes the increase of responsibility of vocational schools for the quality of preparation of the graduates. Thus, there is a need of monitoring of quality of professional preparation of future qualified employees, conducting which is provided by observing certain organizational and pedagogical conditions.

The organizational and pedagogical conditions are understood as a set of favorable circumstances that provide the effectiveness of the organization and conducting of monitoring in the educational establishment. The author presents five main conditions. The first condition: the realization of program of introduction of the complex of monitoring measures corresponding to the specifics of each stage of monitoring (the informational, teaching, preparatory, monitoring and evaluation, analytical-diagnostic, prognostic and managerial). The second condition: the realization of psychological and pedagogical support of monitoring, where the main attention is paid on the motivation of recipients to actively participate in the monitoring process. The third condition: availability of a complex of teaching and methodological support which makes it possible to conduct the active forms of monitoring activities. The fourth condition: the cooperation of all vocational schools of the region with the help of the coordination activity of the Regional Educational and Methodological Center of Vocational Education with the purpose of creating a conditional benchmark for the quality of the training of future skilled workers of particular profession. The fifth condition: ensuring the development of information and analytical competence of the heads of vocational schools.

The author considers that taking into account these basic organizational and pedagogical conditions in the process of monitoring of quality of professional preparation of future qualified employees ensure its effectiveness in the vocational schools and obtain the accurate results.

Keywords: monitoring; monitoring measures; a condition; the organizational and pedagogical conditions; professional training; a future skilled worker; the vocational and technical educational institution.

$\Pi$ остановка проблеми. Реформування національної професійноїосвітиспрямоване на підготовку фахівців нового типу. Це зумовлюєпідвищення відповідальності професійнотехнічних навчальних закладів за якість підготовки своїх випускників. Тому виникає необхідність у моніторингу якості професійної підготовки майбутніх кваліфікованих робітників, проведення якого на належному рівні забезпечується дотриманням певних організаційних та педагогічних умов.

I. Гириловська, 2018
Аналіз останніх публікацій засвідчуе широке коло освітніх проблем, для вирішення яких науковці (А. Галєєва, Д. Горобець, Р. Гуревич, Н. Житник, Л. Петренко, Т. Пятничук, В. Радкевич, Б. Чижевський, та ін.) досліджували різні організаційно-педагогічні умови. Однак, у наукових розробках умови успішного проведення моніторингу якості професійної підготовки учнів в професійно-технічних навчальних закладах (ПТНЗ) не знайшли свого відображення.

Мета статті полягає у теоретичному аналізі 


\section{ОРГАНІЗАЦІЙНО-ПЕДАГОГІЧНІ УМОВИПРОВЕДЕННЯ МОНТТОРИНГУ ЯКОСТІПРОФЕСІЙНОӤ ПЦДГОТОВКИ МАЙБУТНІХ КВАЛІФІКОВАНИХ РОБІТНИКІВ}

організаційно-педагогічних умов проведення моніторингу якості професійної підготовки майбутніх кваліфікованих робітників у ПТНЗ.

Виклад основного матеріалу. Зміст поняття “умова" розкривається через визначення, представлені у тлумачних та філософських словниках $[1 ; 4 ; 5]$. Виокремлюючи спільне у словникових дефініціях, можна констатувати, що під умовами розуміються обставини, які забезпечують виникнення та нормальне функціонування певного явища чи процесу. Умови завжди пов'язані з об'єктом дослідження. Зокрема, професійна підготовка учнів ПТНЗ, як об'єкт моніторингу, надає йому певних особливостей, що слід враховувати при моделюванні усього моніторингового процесу. Так, результати моніторингу цілком і повністю залежать від активності, зацікавленості реципієнтів, інтенсивності їх підготовки до оцінювання, прагнення якнайкраще продемонструвати свої набугі професійні знання та вміння. 3 огляду на це, недоцільно розглядати моніторинг якості професійної підготовки учнів лише як інформаційну основу для прийняття управлінських рішень. Учні не повинні виступати “матеріалом" для отримання необхідних даних, залишаючись пасивними і байдужими впродовж усього моніторингового дослідження, а після нього ставати об'єктом планів, розроблених іншими. За нашим переконанням, моніторинг повинен бути частиною навчального процесу, під час якого випускники узагальнюють та систематизують набуті професійні знання і вміння, продовжують розвивати свої професійні якості, переосмислюють власне професійне майбутнє. Тому, потрібно визначати не лише організаційні, але й педагогічні умови проведення моніторингу якості професійної підготовки учнів у ПТНЗ. Виділяючи відповідні аспекти, звернемося до аналізу поняття “організаційно-педагогічні умови”.

Термін “організаційні” логічно розглядати крізь призму понять “організація”, що забезпечує утворення взаємозв'язків між частинами цілого $[4,463]$ та “управління”, яке підтримує режим діяльності досліджуваного явища [2, 613; 4, 704]. Тому, в контексті нашого дослідження під організаційними умовами розуміються такі обставини, що сприяють узгодженій взаємодії учасників моніторингового процесу, які спільно реалізують певну програму.

Феномен “педагогічні умови” привертає увагу багатьох вітчизняних та зарубіжних дослідників (В. Андреєв, I. Аннєнкова, Ю. Бабанський, С. Висоцький, Ю. Загородній, А. Зубко, М. Малькова, В. Манько, А. Найн, В. Полонський,
Л. Сушенцева, та ін.). Аналіз праць вчених свідчить про відсутність єдиного підходу до визначення даного поняття, але в більшості з них наголошується на тому, що педагогічні умови мають значний вплив на перебіг педагогічного процесу. Зокрема, від них залежить ефективність функціонування педагогічної системи (Ю. Бабанський); вони забезпечують високу результативність навчального процесу i відповідають психолого-педагогічним критеріям оптимальності (В. Манько); ними забезпечується успішне вирішення поставленого завдання (С. Висоцький); від їх реалізації залежить досягнення поставлених дидактичних цілей (М. Малькова). Погоджуючись 3 такою точкою зору, ми прийняли за основу визначення “педагогічних умов”, представлене у словнику професійної педагогіки [3, 143], за яким, це обставини, які забезпечують цілісний продуктивний педагогічний процес професійної підготовки фахівців, що опосередковується активністю особистості.

Приходимо до висновку, що поняття “організаційно-педагогічні умови” відображує органічне поєднання організацію певного процесу 3 його успішним перебігом, що призводить до отримання встановленої наперед мети. В роботах вітчизняних та зарубіжних науковців, які працювали над визначенням даного поняття (В. Бєліков, А. Галєєва, Д. Горобець, Л. Даниленко, Н. Двулічанська, Н. Житник, Є. Козирєва, С. Павлов, В. Хайруліна, Б. Чижевський та ін.), організаційно-педагогічні умови уявляються певними правилами, які забезпечують ефективність протікання процесів, явищ, діяльності. Важливим є те, що умови можна свідомо створювати, добирати, поєднувати. В результаті, під організаційно-педагогічними умовами у нашому дослідженні будемо розуміти сукупність сприятливих обставин, свідомо створену представниками організаційноуправлінської ланки, для забезпечення результативності організації та проведення моніторингу у навчальному закладі.

Намагаючись поєднати організаційні форми i педагогічне забезпечення ми визначили п'ять основних умов проведення моніторингу якості професійної підготовки майбутніх кваліфікованих робітників у ПТНЗ.

Перша організаційно-педагогічна умова: реалізація програми впровадження комплексу моніторингових заходів.

У нашомудослідженні під моніторингом якості професійної підготовки майбутніх кваліфікованих робітників ми розуміємо комплекс заходів, 


\section{ОРГАНІЗАЦЙНО-ПЕДАГОГІЧНІ УМОВИПРОВЕДЕННЯ МОНІТОРИНГУ ЯКОСТІПРОФЕСІЙНОӤ ПІДГОТОВКИ МАЙБУТНІХ КВАЛІФІКОВАНИХ РОБІТНИКІВ}

спрямованих на отримання достовірної інформації про поточний стан професійної підготовки випускників ПТНЗ з метою подальшого його аналізу та внесення необхідних змін для удосконалення навчально-виховного процесу. Враховуючи, що проведення моніторингу повинно охоплювати управлінський та особистісноучнівський рівні, заходи передбачені як для викладацького складу ПТНЗ так і для учнів. Вони поділяються на п'ять груп і відповідають особливостям кожного етапу моніторингу: інформаційно-настановчому, навчально-підготовчому, моніторингово-оцінювальному, аналітикодіагностичному, прогностично-управлінському. Розглянемо їх.

1. Група інформаційно-настановчих заходів:

- настановчі збори для викладачів ПТНЗ, під час яких відбувається добір координаторів моніторингу, розподіл між ними обов'язків, визначення ступеня відповідальності, постановка завдань;

- настановчі збори для учнів, майбутніх учасників моніторингового оцінювання;

- лекторій для викладачів ПТНЗ, що передбачає поглиблення та оновлення теоретичних знань представників організаційноуправлінської ланки щодо технології проведення даного виду моніторингу;

- мотиваційні заходи для учнів 3 метою формування у них потреби у професійній самоідентифікації, позитивного ставлення до моніторингового процесу, виникнення внугрішньої мотивації до активної участі у моніторинговому оцінюванні.

2. Група навчально-підготовчих заходів:

- заходи, спрямовані на подальший розвиток загальних професійно важливих якостей майбутнього кваліфікованого робітника (наприклад, виставка учнівських професійних портфоліо; проведення випускниками майстеркласів $з$ певних видів робіт відповідної професії для першокурсників; написання випускниками листів-настанов до майбутніх вступників у ПТНЗ, в яких розкриватимуться суть та особливості обраної професіі);

- організація керованої професійно-орієнтованої самопідготовки реципієнтів до моніторингового оцінювання.

3. Група моніторингово-оцінювальних заходів:

- проведення тестових оцінювань 3 перевірки професійних знань учнів та їх готовності до виконання професійної діяльності;

- перевірка рівня сформованості загальних професійно важливих якостей майбутнього кваліфікованого робітника.
4. Група аналітико-діагностичнх заходів:

- здійснення обробки й узагальнення результатів, отриманих під час моніторингового оцінювання $з$ метою встановлення інтегрованого показника рівня професійної підготовки випускників ПТНЗ за окресленою професією;

- оприлюднення результатів моніторингового оцінювання.

5. Група прогностично-управлінських заходів:

- участь керівників ПТНЗ у семінарах по вивченню сучасних методів управління діяльністю навчальних закладів (вивчення технології бенчмаркінгу);

- розробка проекту впровадження у діяльність навчального закладу адаптованого досвіду ПТНЗ-лідера на основі бенчмаркінгу.

Друга організачійно-педагогічна умова: здійснення психолого-педагогічного супроводу моніторингу якості професійної підготовки учнів у ПТНЗ, в якому центральне місце займає мотивація реципієнтів до активної участі у моніторинговому процесі.

Мотивація спонукає особу розвивати свої схильності, можливості, здійснює вплив на ії формування та розкриття творчого потенціалу в майбутній професійній діяльності. Головними засобами мотивації виступають мотивування й стимулювання. Під мотивуванням слід розуміти сукупність фактів, аргументів, доведень, що використовуються для переконання учнів. Стимулювання - це зовнішній вплив на особистість, ㄲï зусилля, старанність, наполегливість, націленість, сумлінність через різноманітні стимули (отримання високих оцінок, грамот, дипломів, матеріальних винагород; виконання наказів; встановлення покарань тощо). Мотиваційний вплив націлений на зростання в учнів інтересу до якості власної професійної підготовки, виникнення стійкого бажання показати найкращі результати під час моніторингового оцінювання, підвищенню самооцінки, розуміння залежності результативності виконуваної роботи від особистої старанності і наполегливості. Мотиваційний вплив на реципієнтів реалізується через моніторингові заходи із використанням системи стимулів.

Третя організачійно-педагогічна умова: наявність комплексу навчально-методичного забезпечення, що уможливлює проведення активних форм моніторингових заходів, учнівських консультацій, підготовку реципієнтів до моніторингового оцінювання, розвиток інформаційно-аналітичної компетентності керівників ПТНЗ

Четверта організаційно-педагогічна умова: налагоджена співпраця усіх ПТНЗ регіону через 
координаційну діяльність обласного Навчальнометодичного центру професійно-технічної освіти (НМЦ ПТО) $з$ метою утворення умовного еталону якості професійної підготовки майбутніх кваліфікованих робітників за певною професією.

П'ята організаційно-педагогічна умова: забезпечення розвитку інформаційно-аналітичної компетентності керівників ПТНЗ.

Проведення моніторингу у навчальному закладі завершується написанням проекту застосування досвіду ПТНЗ-лідера, адаптованого до власної організації, на основі бенчмаркінгу. Але прийняття успішних моніторингових рішень на основі бенчмаркінгового підходу вимагає від керівників ПТНЗ здатності до мисленнєвого включення усистему професійної підготовки учнів та виявлення проблеми там, де інші навіть не здогадуються про іiі існування; умінь синтезувати нові комбінації з відомих ідей і положень, знаходити альтернативні варіанти вирішення управлінських проблем. Тобто, вимагає володіти інформаційно-аналітичною компетентністю, яка у даному випадку полягає не лише в оцінці кількісних і якісних змін стану досліджуваного об'єкту, але й прогнозуванні їх динаміки, проектуванні розвитку самого об'єкту. Розвиток інформаційно-аналітичної компетентності керівників ПТНЗ вбачається, насамперед, у співпраці навчальних закладів з НМЦ ПТО, який забезпечить керівникам відповідний науковометодичний супровід. Під науково-методичним супроводом розуміється участь керівного складу ПТНЗ у різноманітних заходах (наприклад, наукових дослідженнях; інноваційних семінарахпрезентаціях із використанням методів ігрового моделювання; управлінських практикумах; салонах управлінських ідей; майстер-класах тощо), що спрямовані на розвиток їх умінь брати користь із досвіду, впорядковувати свої знання, завчасно бачити й вирішувати проблеми, користуватися індуктивним та дедуктивним методами пізнання, узагальнювати й систематизувати набуті знання з подальшим їх використанням для розробки стратегії розвитку власного навчального закладу з урахуванням його потреб.

Висновки. Отже, врахування виокремлених основних організаційно-педагогічних умов при моделюванні моніторингу якості професійної підготовки майбутніх кваліфікованих робітників забезпечить ефективність його проведення в ПТНЗ та отримання достовірних результатів. Перспективи подальших розвідок вбачаються у розробці методики проведення даного виду моніторингу із дотриманням окреслених організаційно-педагогічних умов.

\section{ЛІТЕРАТУРА}

1. Великий тлумачний словник сучасної української мови / Уклад. і голов. ред. В.Т. Бусел. - К.: Ірпінь: ВТФ “Перун”, 2007. - 1736 с.

2. Енциклопедія освіти / голов. ред. В. Г. Кремень. - К.: Юрінком Інтер, 2008. - 1040 с.

3. Словник-довідник з професійної педагогіки / [ред.-упоряд. А. В. Семенова] - Одес: Пальміра, 2006. $-272 \mathrm{c}$.

4. Философский энциклопедический словарь / глав. редакция: Л. Ф. Ильичев, П. Н. Федосеев, С. М. Ковалев и др. - М.: Советская энциклопедия, 1983. - 840 с.

5. Философский энциклопедический словарь / [ред. состав: Е. Губский, Г. Кораблева, В. Лутченко]. - М.: ИНФРА-М, 2000. - 576 c.

\section{REFERENCES}

1. Busel, V.T. (2007). Velykyi tlumachnyi slovnyk suchasnoi ukrainskoi movy [Great explanatory dictionary of modern Ukrainian language]. Kyiv: Irpin, 1736 p. [in Ukrainian].

2. Kremen, V.H. (2008). Entsyklopediia osvity [Encyclopedia of Education]. Kyiv: Yurinkom Inter, 1040 p. [in Ukrainian].

3. Semenova, A.V. (2006). Slovnyk-dovidnyk z profesiinoi pedahohiky [Dictionary of reference on professional pedagogy]. Odesa: Palmira, 272 p. [in Ukrainian].

4. Ilichev, L.F., Fedoseev, P.N. \& Kovalev, S.M. (1983). Filosofskiy entsiklopedicheskiy slovar [Philosophical Encyclopedic Dictionary]. Moscow: Sovetskaya entsiklopediya, 840 p. [in Russian].

5. Gubskiy, E., Korableva, G. \& Lutchenko, V. (2000). Filosofskiy entsiklopedicheskiy slovar [Philosophical Encyclopedic Dictionary]. Moscow: INFRA-M 576 p. [in Russian].

Стаття надійшла до редакції 08.05.2018

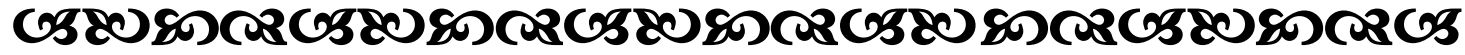

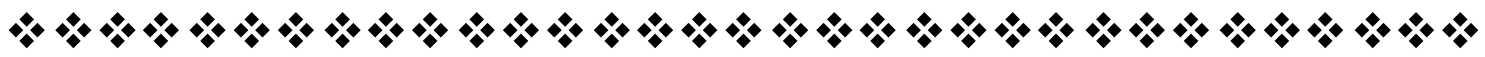

